\title{
Evaluation of Anti-inflammatory and Anti- diarrhoeal Activity of Leaf Aqueous Extracts of Zizyphus Lotus (L) in Albino Wistar Rats
}

\author{
Amira Fatma HANI ${ }^{1-2}$, Mohamed ZAOUANI ${ }^{1-3}$, Nora MIMOUNE ${ }^{1-4}$,ynda AINOUZ ${ }^{1-5}$, Baya DJELLOUT ${ }^{1-6}$, \\ Hayat REMICHI ${ }^{1}$, Sofiane BOUDJELLABA ${ }^{1}$ Afaf BOUCHOUCHA ${ }^{1-7 .}$ \\ ${ }^{1}$ Higher National Veterinary School, Algiers, Algeria \\ ${ }^{2}$ Laboratory of Food Hygiene and Quality Insurance System, Higher National Veterinary School, Algiers, \\ Algeria \\ ${ }^{3}$ Research Laboratory Management of Local Animal Resources, Higher National Veterinary School, \\ Algiers, Algeria \\ ${ }^{4}$ Laboratory of biotechnology related to animal breeding, Institute of Veterinary Sciences, University Saad \\ Dahleb, BP: 270, Soumaa road, Blida 01, Algeria \\ ${ }^{5}$ Laboratory of Biology and Animal Physiology, ENS Kouba, Algiers, Algeria \\ ${ }^{6}$ Laboratory of Research, Health and Animal Productions, Higher National Veterinary School, Algiers, \\ Algeria \\ ${ }^{7}$ Hydrometallurgy and Molecular Inorganic Chemistry Laboratory, Faculty of chemistry, Houari \\ Boumediene Technologies Sciences University (U.S.T.H.B), BP 32 El Alia, Algiers, Algeria \\ *corresponding author: m.zaouani@ensv.dz \\ Bulletin UASVM Veterinary Medicine 77(1)/2020 \\ Print ISSN 1843-5270; Electronic ISSN 1843-5378 \\ doi:10.15835/buasvmcn-vm: 2019.0041
}

\begin{abstract}
The present study was carried out to investigate the phytochemical screening, the acute toxicity, in vivo antiinflammatory and anti-diarrheal activities of the Zizyphus lotus ( $Z$ lotus) leaf's aqueous extract. The extract was subjected to phytochemical analysis, acute toxicity study, anti-inflammatory evaluation using carrageenan induced paw edema and the anti-diarrheal activity was assessed by the castor oil induced diarrhea inhibition method in laboratory rats. The preliminary phytochemical screening of the extract revealed the presence of saponins, flavonoids, and triterpenoids. The extract at the doses used caused a significant $(\mathrm{P}<0.05)$ reduction in the wet feces dumped by the rat with the castor oil-induced diarrhea, and decreased the distance travelled by the charcoal meal. The results showed that the extract of Zizyphus lotus has a significant antidiarrheal and anti-inflammatory activity which supports its use in traditional herbal medicine practice.
\end{abstract}

Keywords: Acute toxicity; leaf aqueous extracts; anti-diarrhoeal and anti-inflammatory activity; phytochemical; Zizyphus lotus

\section{Introduction}

Zizyphus, known as jujube, (commonly called in Algeria sedra), belongs to the family of Rhamnaceae. As a tropical and subtropical plant, $Z$ lotus usually grows in arid and semi-arid countries and is widespread in Africa, especially in Algeria.
Several parts of Ziziyphus plants are widely used in traditional medicine for the treatment of many diseases (Baba, 1999), such as gastrointestinal and liver disorders, urinary tract and skin infections, and diabetes (Glombitza et al., 1994; Renault et al., 1997; Croueour et al., 2002). In the 
recent years, several scientific reports have been made on the presence of numerous biologically active molecules of $Z$ lotus, which could have beneficial effects on nutrition, health, and human and animal diseases (Chouaibi et al., 2012a). In herbal medicine, the properties of bioactive compounds depend on all parts of the plant (root, leaf stem, pulp or fruit) and the type of extract used. $Z$ lotus is known for its high content of polyphenols with antioxidant and antimicrobial immuno-modulatory properties (Ghazghazi et al., 2014; Abdoul-Azize et al., 2013). In addition to other biologically active molecules, we mentioned cyclopeptide alkaloids, known as lotusins (Ghedira et al., 1993), saponins, dammarane and various flavonoids (Borgi et al., 2008) which were isolated from this shrub, as well as polyunsaturated fatty acids (oleic and linoleic acid). These latter are a characterized by a high carbohydrate content and fibers, rich in seed extracts and endowed with anti-ulcerogenic properties and antioxidant effects (Chouaibi et al., 2012b; Abdeddaim et al., 2014). Hence, the present study aims to identify the phytochemical constituents, the acute toxic effects, and to demonstrate that the $Z$ lotus leaf extract can be used as a traditional antidiarrheal and anti-inflammatory remedy.

\section{Materials and methods}

Fresh green $Z$ lotus were collected in Summer 2014 at the Interior town Djelfa, located in, northcentral Algeria, Djelfa has no shores, from the Oulad Naïl Mountains at an elevation of 3.734 feet (1.138 meters). It is situated between the towns of Bou Saâda and Laghouat. A taxonomist from Botany Higher National Agronomic School Departments, Algiers, authenticated the leaves. A voucher specimen was deposited at the Giffen Herbarium of Higher National Veterinary School, Algiers for future reference.

The aqueous extracts were obtained by using an adaptation of the method developed by GuedeGuina et al. (1995). Thus, $50 \mathrm{~g}$ of leaf powder were put with $500 \mathrm{~mL}$ of distilled water to macerate) on a magnetic agitator for $72 \mathrm{~h}$ at room temperature. The homogenate was then filtered using clean cotton wool and Whatman paper $\mathrm{N}^{\circ} 1$. This filtrate underwent evaporation under reduced pressure using a Rotavapor at $40^{\circ} \mathrm{C}$ then was lyophilized for 12 hours and the collected product was preserved in a refrigerator at $4^{\circ} \mathrm{C}$ for further use. Lyophilized leaves were then a dried form.

\section{Experimental animals}

The study was performed on adult Wistar rats of both sexes with an average weight of $200 \pm 20 \mathrm{~g}$, obtained from the Pasteur Institute of Algiers. The control animals and treated animals were maintained under standard environmental conditions (temperature of $22 \pm 3^{\circ} \mathrm{C}$, relative humidity: 55-65\% and $12 \mathrm{~h}$ light/ dark cycle) and had free access to food and water ad libitum.

\section{Guideline for the Care and Use}

All studies were conducted in accordance with Guide for the Care and Use of Laboratory Animals and approved by the Laboratory Research Council of Higher National Veterinary School, Algiers Algeria. All the experiments were carried out according to the guidelines of the Institutional Animal Care Committee of the Algerian Higher Education and Scientific Research. (Agreement Number 45/DGLPAG/DVA.SDA.14).

\section{Preliminary phytochemical screening}

The preliminary phytochemical screening was performed qualitatively using several chemical tests to detect the presence or absence of various classes of phytoconstituents the $Z$ lotus extract solution. Phytoconstituents like flavonoids, alkaloids, saponins, tannins, sterols, and terpenes were identified based on the changes in color of the different reagents that were used in accordance with the standard procedures described by Harborne (1973) and Evans (1989).

\section{Acute toxicity study}

The Acute toxicity test was performed as per OECD guideline 423 for chemicals testing (2001). Five rats per sex were administered a single oral dose of $2000 \mathrm{mg} / \mathrm{kg}$ body weight while the control group received water vehicle. The rats were under continuous observation individually for $30 \mathrm{~min}$, then for the first $24 \mathrm{~h}$, with special attention given during the first $4 \mathrm{~h}$, and daily thereafter, for a total of 14 days in order to record any mortalities or/ and the appearance of general signs and symptoms of toxicity.

\section{Anti- inflammatory activities of the extract; Carrageenan-induced paw Oedema; Anti-inflammatory activity}

The anti-inflammatory activity of the $Z$ lotus aqueous leaf extracts was investigated in a Carrageenan-induced inflammatory model. Acute inflammation was induced in rats by the method of Winter et al., (1962). The control group was administered a saline solution only, while the 
third group was treated with diclofenac sodium. Diclofenac sodium was the preferred positive control substance in studies to compare the results of the test with the known anti-inflammatory activity of the drug $10 \mathrm{mg} / \mathrm{kg}$ p.o. The fourth, fifth and sixth groups were administered the leaf aqueous extracts $(100,200$ and $300 \mathrm{mg} / \mathrm{kg} /$ day p.o. respectively).

The acute inflammatory Oedema was produced by sub-plantar injection of $0.1 \mathrm{ml} 1 \%$ $\mathrm{w} / \mathrm{v}$ suspension of Carrageenan in normal saline, in the right hind paw of the rats, $1 \mathrm{~h}$ after the oral administration of the doses of the $Z$ lotus aqueous leaf extract, positive (Diclofenac) and negative control (carrageenan) substances to the overnight fasted rats. The thickness $(\mathrm{mm})$ of the paw was measured immediately and at 60 minutes interval for four hours after the Carrageenan injection, using vernier calliper (Vasudevan et al., 2006)

The perimeter of paw was measured by using vernier callipers. Measurements were taken at 0-4 $\mathrm{h}$ after the administration of the carrageenan.

The anti-inflammatory activity was calculated by using the relation $\mathrm{T}$, Thickness of paw in control group; T0, Thickness of paw edema in the test compound treated group.

$\%$ inhibition of edema $=(\mathrm{T}-\mathrm{T} 0 / \mathrm{T}) \times 100$

\section{Antidiarrhoeal activity; Castor oil induced diarrhoea in rats.}

Castor oil was used to induce diarrhoea according to the method described by Awouters et al. (1978). Male rats (200-220 g) were fasted for $18 \mathrm{~h}$. They were divided into five groups $(n=6)$. Being the control group, group I rats were orally administered normal saline solution (2 mL/ $\mathrm{kg}$ ). The second group received standard drug, loperamide ( $2 \mathrm{mg} / \mathrm{kg}$ ) orally as suspension. Doses of 100,200 and $300 \mathrm{mg} / \mathrm{kg}$ body weight of $Z$ lotus aqueous extract were orally administered to the groups III, IV and V respectively. After $60 \mathrm{~min}$ of the drug treatment, the animals of each group orally received $1 \mathrm{~mL}$ of castor oil. The watery faecal material and the number of defecations were noted for up to $4 \mathrm{~h}$ in the transparent metabolic cages with filter papers at the base. The Weight of the paper before and after the defecation was noted.

The total diarrhoea faeces for the control group were considered $100 \%$. The results were expressed as a percentage of inhibition of diarrhoea. The percentage of defecation inhibition was calculated as follows:

$\%$ of Defecation Inhibition of defecation $=\frac{A-B}{A} X 100$

A indicates the average number of defecations caused by castor oil;

$B$ (indicates the average number of defecations after administration of the drug and $\mathrm{z}$ lotus extract).

\section{Gastrointestinal motility assay}

Gastrointestinal motility assay was performed according to the method described by Chitme et al., (2004). The experimental rats were completely randomized into five groups of six animals each. The negative control group orally received saline $(2 \mathrm{~mL} / \mathrm{kg})$ as the control group. The positive control group II orally received the standard drug, loperamide ( $5 \mathrm{mg} / \mathrm{kg}$ body weight). Doses of 100,200 and $300 \mathrm{mg} / \mathrm{kg}$ body weight of $Z$ lotus aqueous extract were orally administered to the groups III, IV and V respectively. Thirty minutes after the drug administration, $1 \mathrm{~mL}$ of charcoal meal (5\%) was orally administered to all animals and 30 min later, all the rats were euthanized by cervical dislocation and their abdomens were opened to measure the distance travelled by the activated charcoal. The results were expressed as percentage of the total length of the intestine from the pylorus to the caecum:

$$
\text { Inhibition }(\%)=\frac{\text { Dcontrol }- \text { Dtreated }}{\text { Dcontrol }} \times 100
$$

D control $=$ weight of intestinal content in control group;

D treated $=$ weight of intestinal content in treated group.

\section{Statistical analysis}

Statistical analysis was performed using STATISTICA (Version 10, Stat Soft France, 2003). All the values were expressed as mean \pm SD. The data were assessed using one-way analysis of variance (ANOVA). Statistical significance was accepted at $\mathrm{p}<0.05$. 


\section{Results and discussions \\ Phytochemical screening}

During this phytochemical study, the screening allowed us to characterize the different families of existing chemical compounds in the $Z$ lotus leaves' aqueous extract. The results of the phytochemical tests performed on the extracts from the leaves, reveal the presence of all the elements analyzed: Flavonoids, alkaloids, saponins, tannins, sterols, and terpenes. The phytochemical screening results are illustrated in Table 1.

\section{Acute toxicity}

Limit test was performed at $2000 \mathrm{mg} / \mathrm{kg}$ as single dose; the animals did not develop any visible signs of toxicity, and no mortality at the dose $(2000 \mathrm{mg} / \mathrm{kg}$ ). Therefore, the LD50 of the aqueous extract of $\mathrm{Z}$ lotus could be classified in Globally Harmonized Classification System for Chemical Substances and Mixtures (GHS), hazard category 5 with a LD50 ranging from $2000 \mathrm{mg} / \mathrm{kg}$ and $5000 \mathrm{mg} / \mathrm{kg}$ orally in rats

Anti-inflammatory activity. Effect of the of the $Z$ lotus leaf's aqueous extract on carrageenan induced rat paw 0edema.

The results of the anti-inflammatory activity of the $Z$ lotus leaf's aqueous extract at the doses of 100,200 and $300 \mathrm{mg} / \mathrm{kg}$ against paw Oedema induced by carrageenan are shown in Table 2 . The Maximum edematous inflammation was obtained $3 \mathrm{~h}$ after the administration. The volume of paw oedema varies with time. After one hour of carrageenan injection. The antiinflammatory activity data indicated that all the test concentrations (100, 200 and $300 \mathrm{mg} / \mathrm{kg}$ ) were able to significantly reduce the carrageenaninduced oedema at different times after the injection of the phlogistic agent, in comparison to control $(\mathrm{p}<0.05)$ increased activity after 2 hours, the reduction of the oedema by the aqueous extract of the $Z$ lotus leaf at the dose of $300 \mathrm{mg} /$ $\mathrm{kg}$ was similar to the standard used (diclofenac) throughout the entire period of the observation, No significant difference was observed in oedema inhibition in the standard group (diclofenac $10 \mathrm{mg} /$ $\mathrm{kg}$ ) and the group of the $Z$ lotus leaf's aqueous extract at the doses of 100, 200 and $300 \mathrm{mg} /$ $\mathrm{kg}$ against paw oedema induced by carrageenan (Table 2).

Determination of anti-diarrhoeal activity. Effect of castor-oil-induced diarrhoeal

In the castor oil-induced diarrhoea experiment, the aqueous extract of $Z$ lotus leaves produced a marked antidiarrheal effect in the rats as shown in table 3, Diarrhoea was clinically apparent in all the animals of the control group 45 min after administration of castor oil for the next 4 hours. A significant $(\mathrm{p}<0.05)$ reduction in the number of defecations over the length of the four hours was achieved with the aqueous extract of the $Z$ lotus leaves when compared to the control. Generally, all doses of the plant extracts had practically reacted like loperamide, Highest inhibition percentage of defecation in the extract treated groups was observed at $300 \mathrm{mg} / \mathrm{kg}$ (73.40. $\%$ ), while the Loperamide retained the maximum percentage inhibition of defecation (80.25\%).

\section{Effect of castor oil-induced}

\section{gastrointestinal motility}

The results illustrated in table 4 from the gastrointestinal motility tests showed that the speed of intestinal transit followed the same pattern as in the castor-oil-induced diarrhoeal, and were as follows: the average distance moved by the charcoal marker was greatest for the control group

Table1. Phytochemical constituents in the $Z$ lotus leaf's aqueous extract

\begin{tabular}{cc}
\hline Phytochemical constituents & Relative presence \\
\hline Flavonoids & + \\
\hline Alkaloids & + \\
\hline Saponins & + \\
\hline Tannins & + \\
\hline Sterols & + \\
\hline Terpenes & + \\
\hline
\end{tabular}

+: presence of specific phytoconstituents; -: absence of specific phytoconstituents. 
(group I). The aqueous extract of the $Z$ lotus leaves significantly $(\mathrm{p}<0.05)$ decreased propulsion of the charcoal meal in the rat gastrointestinal tract and was based on the three doses of extract $(100,100$ and $300 \mathrm{mg} / \mathrm{kg}$ (p.o), compared with the control group that received normal saline $(2 \mathrm{ml} / \mathrm{kg}$ ) (Table 4). The effect is comparable to that of the standard drug loperamide (5 mg/kg) which markedly better reduced the propulsion of charcoal meal through gastrointestinal tract.

Preliminary phytochemical screening of aqueous leaf extract of $Z$ lotus revealed the presence of various chemical constituents. This result was in agreement with earlier findings where the presence of phytochemicals like flavonoids, tannins, saponins, cardiac glycosides, triterpenoids and alkaloids were detected in the plant (Slimani et al., 2017). These phytochemical constituents are physiologically active compounds possessing great potential for therapeutic and prophylactic uses (Jivad et al., 2016). Some of these molecules have been documented to possess interesting anti-inflammatory (Perez, 2001; Han and Bakovic, 2015; Patil et al., 2019) and antidiarrheal proper-

Table 2. Anti-inflammatory effect of the $Z$ lotus leaf's aqueous extract on carrageenan-induced rats (mean $\pm \mathrm{SD}$ )

\begin{tabular}{|c|c|c|c|c|c|c|}
\hline \multirow[t]{2}{*}{ Groups } & \multirow[t]{2}{*}{$\begin{array}{c}\text { Dose } \\
\text { (mg/kg) p.o. }\end{array}$} & \multicolumn{4}{|c|}{ Edema Size Means (mm) \pm SD (\%Inhibition) } & \multirow{2}{*}{$\begin{array}{c}\% \\
\text { inhibition }\end{array}$} \\
\hline & & $\mathbf{1}^{\text {st }} \mathbf{h}$ & $2^{\text {st }} \mathbf{h}$ & $3^{\text {st }} h$ & $4^{\text {st }} h$ & \\
\hline Control Carrageenan & & $5.96 \pm 0.04$ & $5.98 \pm 0.03$ & $6.54 \pm .006$ & $6.85 \pm 0.06$ & - \\
\hline $\begin{array}{l}\text { Carrageenan } \\
+ \text { diclofenac }\end{array}$ & 10 & $\begin{array}{c}4.04 \pm 0.21 * \\
32.21\end{array}$ & $\begin{array}{c}3.03 \pm 0.24 * \\
49.33\end{array}$ & $\begin{array}{c}2.79 \pm 0.23 * \\
57.33\end{array}$ & $\begin{array}{c}2.44 \pm 0.23 * \\
64.37\end{array}$ & 50.81 \\
\hline $\begin{array}{l}\text { Carrageenan } \\
+ \text { aqueous extract }\end{array}$ & 100 & $\begin{array}{c}4.40 \pm 0.34 * \\
26.17\end{array}$ & $\begin{array}{c}3.85 \pm 0.11 * \\
35.61\end{array}$ & $\begin{array}{c}3.14 \pm 0.21 * \\
51.98\end{array}$ & $\begin{array}{c}3.08 \pm 0.10 * \\
55.03\end{array}$ & 42.19 \\
\hline $\begin{array}{l}\text { Carrageenan } \\
+ \text { aqueous extract }\end{array}$ & 200 & $\begin{array}{c}4.25 \pm 0.21 * \\
28.69\end{array}$ & $\begin{array}{c}3.69 \pm 0.32 * \\
38.29\end{array}$ & $\begin{array}{c}3.42 \pm 0.31 * \\
\quad 47.70\end{array}$ & $\begin{array}{c}3.02 \pm 0.22 * \\
55.91\end{array}$ & 42.64 \\
\hline $\begin{array}{l}\text { Carrageenan } \\
+ \text { aqueous extract }\end{array}$ & 300 & $\begin{array}{c}4.23 \pm 0.13 * \\
29.02\end{array}$ & $\begin{array}{c}3.24 \pm 0.32 * \\
45.81\end{array}$ & $\begin{array}{c}2.78 \pm 0.24 * \\
57.49\end{array}$ & $\begin{array}{l}2.67 \pm 0.22 * \\
\quad 61.10\end{array}$ & 48.35 \\
\hline
\end{tabular}

$* \mathrm{P}<0.05$ - significant compared to carragenan treated group.

Table 3. Effect of $Z$ lotus leaf aqueous extract on castor oil-induced diarrhoea in rats

\begin{tabular}{cccc}
\hline Group & $\begin{array}{c}\text { Treatment } \\
\text { Dose }(\mathbf{m g} / \mathbf{k g})\end{array}$ & $\begin{array}{c}\text { Mean number of } \\
\text { defecation after } \mathbf{4} \mathbf{~ h}\end{array}$ & $\begin{array}{c}\text { \% Inhibition } \\
\text { of defaecation }\end{array}$ \\
\hline G1 & $2 \mathrm{~mL}$ normal saline+CO & $6.28 \pm 0.18$ & - \\
\hline G2 & $5 \mathrm{mg} / \mathrm{kg}$ loperamide $+\mathrm{CO}$ & $1.24 \pm 0.23^{*}$ & 80.25 \\
\hline G3 & $100 \mathrm{mg} / \mathrm{kg}$ extract+CO & $2.42 \pm 0.13^{*}$ & 61.46 \\
\hline G4 & $200 \mathrm{mg} / \mathrm{kg}$ extract $+\mathrm{CO}$ & $2.39 \pm 0.21^{*}$ & 61.94 \\
\hline G5 & $300 \mathrm{mg} / \mathrm{kg}$ extract $+\mathrm{CO}$ & $1.67 \pm 0.27^{*}$ & 73.40 \\
\hline
\end{tabular}

*Statistically significant $\mathrm{p}<0.05$ 
Table 4. Effect of $Z$ lotus leaf aqueous extract on charcoal gastrointestinal transit in albino rats

\begin{tabular}{lcccc}
\hline $\begin{array}{c}\text { Treatment } \\
\mathbf{m g} / \mathbf{k g} / \text { Group }\end{array}$ & $\begin{array}{c}\text { Length of small } \\
\text { intestine } \mathbf{( c m )}\end{array}$ & $\begin{array}{c}\text { Distance travelled } \\
\text { by charcoal } \\
\text { meal (cm) }\end{array}$ & $\begin{array}{c}\text { Percentage } \\
\text { intestinal } \\
\text { transit }\end{array}$ & $\begin{array}{c}\text { Percentage } \\
\text { inhibition } \\
\mathbf{( \% )}\end{array}$ \\
\hline Group1 (Control)+CH & $110.60 \pm 2.48$ & $68.73 \pm 4.75$ & 62.14 & - \\
\hline Group 2 (loperamide) +CH & $107.45 \pm 3.42$ & $31.27 \pm 1.18$ & $29.10^{*}$ & 54.50 \\
\hline Group 3 (100)+CH & $107.18 \pm 3.32$ & $46.65 \pm 2.3$ & $43.52^{*}$ & 32.12 \\
\hline Group 4 (200) +CH & $104.85 \pm 4.28$ & $42.10 \pm 3.42$ & $40.15^{*}$ & 38.74 \\
\hline Group 5 (300) +CH & $106.23 \pm 4.52$ & $36.12 \pm 3.18$ & $34^{*}$ & 47.44 \\
\hline
\end{tabular}

*Statistically significant $\mathrm{P}<0.05$ compared to the control, $\mathrm{CH}=$ charcoal.

ties (Rahman et al., 2018). These might be responsible for the activities of the plant extract seen in this study.

We estimated that the LD50 is higher than $2 \mathrm{~g} / \mathrm{kg}$ since we have not observed mortality or signs of toxicity for 14 days, according to the GHS classification, our product belong to the category 5 product slightly or not toxic.

Carrageenan Induced hind paw edema is the standard experimental model of acute inflammation used to assess the antiinflammatory activity of several natural and synthetic compounds (Vogel, 2002; Boominathan et al., 2004). It is the distinctive model of the acute inflammation exhibiting a high degree of reproducibility (Panthong, 2007). Diclofenac $(10 \mathrm{mg} / \mathrm{kg})$ was taken as a standard drug to test anti-inflammatory activity of aqueous leaf extract of $Z$ lotus. Mean increase in paw volume and percentage of inhibition of carrageenan induced paw edema were taken as parameters for assessing anti-inflammatory effect of the test drug.

The development of edema in the paw of the rat after the injection of carrageenan has been described as biphasic event. The initial phase which occurred between 0 and $2.5 \mathrm{~h}$ has been attributed to the action of histamine, serotonin and bradykinin on the vascular permeability (Vinger, 1987). The oedema volume reached its maximum proximately $3 \mathrm{~h}$ post treatment and then began to decline (Vinegar et al., 1969; Rosa and Willoughby, 1971).

Based on the result of the present study, the aqueous extracts of $Z$ lotus significantly decreased antioedematogenic effect in both phases of carrageenan-induced acute inflammation. The extract was found to be comparable to Diclofenac in activity, especially at higher doses. Therefore, it can be inferred that the possible inhibitory effect of aqueous extract of $Z$ lotus in carragenan induced inflammation may be due to inhibition of cycloxygenase leading to inhibition of prostaglandin synthesis. This suggests secondary metabolites present in the plant which may suppress both phases of acute inflammation by interfering with the release and/or activity of the chemical mediators, such as histamine, bradykinin, and serotonin in the first phase. Several studies also reported that the extracts of $Z$ lotus exhibited anti-inflammatory properties (El Hachimi et al., 2017; Zhang et al., 2017).

Aqueous leaf extract of $Z$ lotus was evaluated for its antidiarrheal potential against castor oil induced diarrhea and antimotility effect in charcoal meal test in Wistar rat. In the castor oil induced diarrhea model in rat, castor oil induces diarrhea through its active metabolite, ricinoleic acid which causes the irritation and inflammation of the intestinal mucosa leading to prostaglandins (PGE2 $\alpha$ ) release. The prostaglandins released in the small intestines prevent the reabsorption of sodium chloride and water, Therefore, inhibition of prostaglandins biosynthesis delays castor oilinduced diarrhea (Rahman et al., 2015), like that of non-steroidal anti-inflammatory drugs. Castor oil induced diarrhea is related to stimulation of prostaglandins biosynthesis (Kaur et al., 2014). Thereby, a previous study suggested that the colon anti-inflammatory status activities demonstrated by $Z$ lotus leaf extract improved the inflammatory status. 
The charcoal meal test was carried out to determine the effect of aqueous leaf extract of $Z$ lotus on gut motility. Similarly, to the findings in the castor oil-induced diarrhea model, all doses of the plant extract showed a significant reduction in gastrointestinal transit using charcoal meal. This activity was comparable to that of loperamide used here as reference drug and acts by decreasing the transit velocity and increasing the capacity of the intestines to retain their fluids. It also buttresses the earlier postulation in the castor oil model that this plant extract reduces diarrhea by inhibition of both motility and secretion (Han et al., 2017). So, the antidiarrheal effect of the plant extract may be attributed to the role of bioactive constituents such as tannins and flavonoids in the extract, which have already been reported for their antidiarrheal activity (Zaouani et al., 2018; Mehesare et al., 2019).

The result indicated that aqueous leaf extract possessed significant antidiarrheal activity due to its inhibitory effect both on gastrointestinal propulsion and fluid secretion.

\section{Conclusion}

Existing results of this study confirmed that the aqueous leaf extract of $Z$ lotus showed significant anti-inflammatory and antidiarrheal activities. Our present study also reported the presence of flavonoids, alkaloids, tannins, glycosides. Flavonoids and alkaloids were responsible for the activities of this plant as traditional medicine and acclaimed effectiveness in treating several painful, inflammatory, and diarrheal problems. Moreover, it could be a potential source for anti-inflammatory and antidiarrheal drug development. It may be concluded that the present study supported the traditional use of $Z$ lotus by medical practitioners in the cure of inflammatory, diarrheal and associated disorders.

Acknowledgments. This research did not receive any specific grant from funding agencies in the public, commercial, or not-for-profit sectors.

\section{References}

1. Abdeddaim M, Lombarkia O, Bacha A, Fahloul D, Abdeddaim D, Farhat R, Lekbir A (2014). Biochemical characterization and nutritional properties of Zizyphus lotus l. fruits in aures region, northeastern of Algeria. Food science and technology, 15, 7581.
2. Abdoul-Azize S, Bendahmane M, Hichami A, Dramane G, Simonin AM, Benammar C, Khan NA (2013). Effects of Zizyphus lotus L.(Desf.) polyphenols on Jurkat cell signaling and proliferation. International immunopharmacology, 15(2): 364-371.

3. Awouters F, Niemegeers CJE, Lenaerts FM, Janssen PAJ (1978). Delay of castor oil diarrhoea in rats: a new way to evaluate inhibitors of prostaglandin biosynthesis. Journal of Pharmacy and Pharmacology, 30(1): 41-45.

4. Baba AF (1999). Encyclopédie des plantes utiles. Flores d'Algérie et du Maghreb, Copyright Librairie, Alger, 368 p.

5. Boominathan R, Parimaladevi B, Mandal S C, Ghoshal SK (2004). Anti-inflammatory evaluation of Ionidium suffruticosam Ging. in rats. Journal of ethnopharmacology, 91(2-3): 367-370.

6. Borgi W, Recio MC, Ríos JL, Chouchane N (2008). Antiinflammatory and analgesic activities of flavonoid and saponin fractions from Zizyphus lotus (L.) Lam. South African Journal of Botany, 74(2): 320-324.

7. Chitme H., Chandra R, Kaushik S (2004). Studies on anti-diarrhoeal activity of Calotropis gigantea $\mathrm{R}$. Br. in experimental animals. J Pharm Pharm Sci, 7(1): 70-75.

8. Chouaibi M, Rezig L, Mahfoudhi N, Arafa S, Donsì F, Ferrari G, Hamdi S (2012a). Physicochemical Characteristics and Antioxidant Activities of Zizyphus lotus L. Seed Oil. Journal of Food Biochemistry, 37(5):554-563.

9. Chouaibi N, Mahfoudhi L, Rezig F, Dons G, Ferrari S, Hamdi S (2012b). Nutritional composition of Zizyphus lotus L. seeds. Journal of the Science of Food and Agriculture, 92(6): 1171-1177.

10. Croueour GL, Thepenier P, Richard B, Petermann C, Ghedira K, Zeches-Hanrot M (2002). Lotusine G: a new cyclopeptide alkaloid from Zizyphus lotus. Fitoterapia, 73(1): 63-68

11. El Hachimi F, Alfaiz C, Bendriss A, Cherrah Y, Alaoui K (2017). Activité anti-inflammatoire de l'huile des graines de Zizyphus lotus (L.) Desf. Phytothérapie, 15(3): 147-154.

12. Evans WC (1989). Trease and Evans' Pharmacognosy, London, UK: Bailliere Tindall. Fischer DB (1983). Yearround collection of willow sieve-tube exudate. Planta, 159, 529-533.

13. Ghazghazi H, Aouadhi C, Riahi L, Maaroufi A, Hasnaoui B (2014). Fatty acids composition of Tunisian Ziziphus lotus L.(Desf.) fruits and variation in biological activities between leaf and fruit extracts. Natural product research, 28(14): 1106-1110.

14. Ghedira K, Chemli R, Richard B, Nuzillard JM, Zeches M, Le Men-Olivier L (1993). Two cyclopeptide alkaloids from Zizyphus lotus. Phytochemistry, 32(6): 1591-1594.

15. GHS U (2007). United Nations, Globally Harmonized System of Classification and Labelling of Chemicals, UN New York and Geneva, 2007.

16. Glombitza KW, Mahran GH, Mirhom YW, Michel KG, Motawi TK (1994). Hypoglycemic and antihyperglycemic effects of Zizyphus spina-christi in rats. Planta medica, 60(03): 244-247.

17. Guede-Guina F, Tsai CS, Smith M O, Vangah-Manda M, Washington B, Ochillo RF (1995). The use of isolated 
functional heart to pharmacologically characterize active ingredients in the aqueous extracts of Mareya micrantha. Journal of ethnopharmacology, 45(1): 19-26.

18. Han N, Bakovic M (2015). Biologically active triterpenoids and their cardioprotective and anti-inflammatory effects. J Bioanal Biomed S, 12(005): 1948-59.

19. Han S H, Park K, Kim EY, Ahn SH, Lee HS, Suh HJ (2017). Cactus (Opuntia humifusa) water extract ameliorates loperamide-induced constipation in rats. BMC complementary and alternative medicine, 17(1):49.

20. Harborne J B (1973). Phytochemical methods chapman and Hall. Ltd. London, 4, 49-188.

21. Jivad N, Bahmani, Asadi-Samani M (2016). A review of the most important medicinal plants effective on wound healing on ethnobotany evidence of Iran. Der Pharmacia Lettre, 8(2):353-357.

22. Kaur, Mohanjit, Singh, Amarjeet, Kumar, Bimlesh. (2014). Comparative antidiarrheal and antiulcer effect of the aqueous and ethanolic stem bark extracts of Tinospora cordifolia in rats. Journal of Advanced Pharmaceutical Technology Research. 5. 122-8. 10.4103/22314040.137417.

23. Mehesare SS, Waghmare SP, Thorat MG, Hajare SW, Itankar PR, Ali SS (2019). Evaluation of antidiarrhoeal activity of extract of unripe fruit of Aegle marmelos. Journal of Pharmacognosy and Phytochemistry, 8(4): 2390-2392.

24. Panthong A, Norkaew P, Kanjanapothi D, Taesotikul T, Anantachoke N, Reutrakul V (2007). Anti-inflammatory, analgesic and antipyretic activities of the extract of gamboge from Garcinia hanburyi Hook f. Journal of ethnopharmacology, 111(2): 335-340.

25. Patil KR, Mahajan UB, Unger BS, Goyal SN, Belemkar S, Surana SJ, Patil CR (2019). Animal Models of Inflammation for Screening of Anti-inflammatory Drugs: Implications for the Discovery and Development of Phytopharmaceuticals. International Journal of Molecular Sciences, 20(18): 4367.

26. Perez G (2001). Anti-inflammatory activity of compounds isolated from plants. The Scientific World Journal, 1, 713784.

27. Rahman M, Chowdhury M, Uddin A, Islam MT, Uddin ME, Sumi CD (2015). Evaluation of antidiarrheal activity of methanolic extract of Maranta arundinacea Linn. leaves. Advances in pharmacological sciences, 2015.
28. Rahman M, Ferdous N, Alamgir A (2018). Secondary Metabolites and Bioactivities of Melastoma Malabathricum (L.) Smith: An Anti-Diarrheal Plant of Bangladesh. To Chemistry Journal, 1(3): 256-262.

29. Renault JH, Ghedira K, Thepenier P, Lavaud C, ZechesHanrot M, Le Men-Olivier L (1997). Dammarane saponins from Zizyphus lotus. Phytochemistry, 44(7):1321-1327.

30. Rosa M D, Willoughby DA (1971). Screens for antiinflammatory drugs. Journal of Pharmacy and Pharmacology, 23(4): 297-298.

31. Slimani A, Abdellah M, Hamadi L (2017). Phytochemical screening, contribution to the study of the antifungal effect of flavonoids from different parts of Ziziphus lotus of south-west Algeria. Asian Journal of Pharmaceutical and Clinical Research, 13-16.

32. Vasudevan M, Gunnam KK, Parle M (2006). Antinociceptive and anti-inflammatory properties of Daucus carota seeds extract. Journal of health science, 52(5): 598-606.

33. Vinegar R, Schreiber W, Hugo R (1969). Biphasic development of carrageenin edema in rats. Journal of pharmacology and experimental therapeutics, 166(1): 96-103.

34. Vinger P F (1987). The One-Eyed Athlete. The Physician and sportsmedicine, 15(2): 48.

35. Vogel HG (2002). Drug discovery and evaluation: pharmacological assays. (Ed.) Springer Science \& Business Media.

36. Winter CA, Risley EA, Nuss GW (1962). Carrageenininduced edema in hind paw of the rat as an assay for antiinflammatory drugs. Proceedings of the society for experimental biology and medicine, 111(3): 544-547.

37. Zaouani M, Yahiaoui F, Nacer Bey N, Ben-Mahdi MH (2018). Antidiarrhoeal activity of aqueous leaf extract of Olea europaea var. sylvestris in albino Wistar rats. Journal of Biological Research-Bollettino della Società Italiana di Biologia Sperimentale, 91(2).

38. Zhang L, Liu X, Wang Y, Liu G, Zhang Z, Zhao Z, Cheng H (2017). In vitro antioxidative and immunological activities of polysaccharides from Zizyphus Jujuba cv. Muzao. International journal of biological macromolecules, 95, 1119-1125. 